\title{
Effectiveness of Storage Time Formulation of Bacillus Thuringiensis Against Aedes aegypti Larvae (Linnaeus)
}

\author{
Melanie $^{1 *}$, Mia Miranti Rustama², Inriyani Sintia Sihotang ${ }^{2}$, Hikmat Kasmara² \\ ${ }^{1}$ Doctoral student of Study Program of Environmental Sciences, Universitas Padjadjaran, Jatinangor, West Java, Indonesia, \\ 45363 \\ ${ }^{2}$ Departement Biology, Faculty of Mathematic and Natural Sciences, Universitas Padjadjaran, Jatinangor, West Java, \\ Indonesia, 45363 \\ ${ }^{2}$ Graduate of Departement Biology, Faculty of Mathematic and Natural Sciences, Universitas Padjadjaran, West Java, \\ Indonesia, 45363
}

*Corresponding author: melie_entobio@yahoo.com

\begin{abstract}
Aedes aegypti is known as the main vector of dengue fever in Indonesia which causes a high number of deaths and become an outbreak every year. This disease is generally controlled by breaking the life cycle of mosquitoes with restricted breeds and using synthetic insecticides. So far biological agents from natural enemies and natural pathogens have been developed to anticipate the negative effects of synthetic insecticides. Bacillus thuringiensis is well known as entomopathogenic bacteria that can control various insect pests of cultivated plants and vector insects, such as Ae.aegypti. B. thuringiensis can form endospores that produced toxin to Ae. aegypti, while the advatages are safe against non-target organisms such as natural predators and parasites, safe for mammals and humans and do not pollute the environment. Effective duration of $B$. thuringiensis in infecting Ae. aegypti is an important thing to be studied, moreover it is important to know the effectiveness of the expired formulation on the market and the residual effect. This ensures that the use of $B$. thuringiensis remains safe and does not create new problems such as Ae. aegypti resistance. The experimental research was used bioassay method, toxicity test was performed $B$. thuringiensis expired and non expire as comparison at concentration 0 ppm (control), 0,3 ppm; $0.1 \mathrm{ppm} ; 0.07 \mathrm{ppm} ; 0.05 \mathrm{ppm} ; 0.03 \mathrm{ppm} ; 0.01 \mathrm{ppm}$. The parameters observed were mortality for 48 hours of toxicity test that results were indicated by $\mathrm{LC}_{50}, \mathrm{LC}_{90}$ and recidual values. The results obtained were $\mathrm{LC}_{50}$ and $\mathrm{LC}_{90}$ formulations $B$. thuringiensis expired $0.305 \mathrm{ppm}$ and $1.513 \mathrm{ppm}$ much higher than the non expire $\mathrm{LC}_{50}$ and $\mathrm{LC}_{90}$ formulations of $0.036 \mathrm{ppm}$ and $0.897 \mathrm{ppm}$. The recidual effect of expired B. thuringiensis on larvae Ae. Aegypti was only effective until day 12, whereas $B$. thuringiensis that non expire formulation was effectively until day 14.
\end{abstract}

Keywords : Ae. aegypti, B. thuringiensis, mortality, recidual values, expired formulation

\section{ABSTRAK}

\section{Efektivitas Waktu Simpan Formulasi Bacillus thuringiensis Terhadap Larva Aedes aegypti (Linnaeus)}

Nyamuk Aedes aegypti dikenal sebagai vektor utama Penyakit DBD di Indonesia yang merupakan penyakit dengan tingkat kematian yang tinggi dan menjadi wabah setiap tahun. Cara pengendalian yang umum dilakukan dengan memutus siklus hidup nyamuk melalui membatasi perkembangbiakan nyamuk serta menggunakan insektisida sintetik. Pengendalian hayati yang menekan efek negatif insektisida sintetik sejauh ini dikembangkan dari musuh alami nyamuk baik predator maupun entomopatogen. Musuh alami dari jenis bakteri entomopatogen Bacillus thuringiensis telah lama dikenal mampu mengendalikan berbagai serangga hama tanaman budidaya maupun serangga vektor penyakit, diantaranya Ae. aegypti. B. thuringiensis memiliki metabolit sekunder yang di produksi oleh endosporanya yang bersifat toksik terhadap nyamuk $A e$. aegypti, kelebihanya adalah aman terhadap organisme non target seperti predator dan parasit alami, aman bagi mamalia maupun manusia serta tidak mencemari lingkungan. Rentang waktu efektivitas B. thuringiensis dalam menginfeksi Ae. Aegypti hal yang penting untuk diteliti terlebih lagi penting mengetahui efektivitas dari formulasi yang telah lewat masa simpan di pasaran serta efek residunya. Hal ini yang memastikan penggunaan $B$. thuringiensis tetap aman dan tidak menimbulkan masalah baru yaitu resistensi nyamuk Ae. Aegypti. Melalui penelitian yang menggunakan metode eksperimental dengan bioassay, dilakukan uji toksisitas B. thuringiensis kadaluarsa dan tidak kadaluarsa sebagai pembanding pada konsentrasi 0 ppm (kontrol), 0,3 ppm; 0,1 ppm; 0,07 ppm; 0,05 ppm; 0,03 ppm; 0,01 ppm. Parameter yang diamati mortalitas selama 48 jam pengujian yang ditunjukkan oleh nilai $\mathrm{LC}_{50}$ dan $\mathrm{LC}_{90}$ selama 48 jam, dan nilai residu. Hasil yang diperoleh adalah $\mathrm{LC}_{50}$ dan $\mathrm{LC}_{90}$ formulasi $B$. thuringiensis yang kadaluarsa $0,305 \mathrm{ppm}$ dan $1,513 \mathrm{ppm}$ jauh lebih tinggi dari nilai $\mathrm{LC}_{50}$ dan $\mathrm{LC}_{90}$ formulasi yang tidak kadaluarsa yaitu $0,0363 \mathrm{ppm}$ dan $0,8971 \mathrm{ppm}$. Efek residu B. thuringiensis yang kadaluarsa terhadap larva Ae. Aegypti efektif hanya hingga hari ke-12, adapun B. thuringiensis yang tidak kadaluarsa efektif hingga hari ke-14.

Kata kunci: Ae. aegypti, B. thuringiensis, mortalitas, efek residu, kadaluarsa

\section{PENDAHULUAN}

Aedes aegypti merupakan vektor utama dalam penyebaran penyakit Demam Berdarah Dengue (Depkes, 2007). Penyakit ini menimbulkan kematian yang cukup tinggi setiap tahun, sampai saat ini vaksin Virus Demam Berdarah Dengue (DBD) masih terus dikembangkan dan belum umum digunakan, sehingga salah satu cara pencegahannya adalah dengan memutuskan rantai penularan dengan memberantas vektornya (Fathi dkk. 2005). Usaha penanggulangan umumnya melalui pengendalian nyamuk dengan fogging, yaitu pengasapan yang dilakukan dengan 
ultra low volume (ULV) (Boesri 2008). Penanggulangan terhadap larva nyamuk dilakukan dengan penebaran abate sebagai larvasida pada tempat pembiakan nyamuk (Depkes, 2007). Penggunaan insektisida kimiawi secara umum dirasa sangat berhasil dalam mengendalikan serangga vektor penyakit seperti nyamuk, namun penggunaan insektisida yang terus menerus akan menyebabkan resistensi nyamuk, meninggalkan residu dan mengganggu kesehatan seperti gangguan pernafasan dan iritasi kulit.

Upaya pengendalian nyamuk dikembangkan pula melalui pengendalian hayati menggunakan bio agen yang merupakan patogen serangga, diantaranya menggunakan bakteri entomopatogen Bacillus thuringiensis. Bakteri ini berbentuk batang, gram positif, dapat membentuk endospora yang menghasilkan kristal protein. Kristal protein merupakan kelas endotoksin delta yang dikenal dengan protein atau toksin Cry. Dalam tubuh serangga toksin tersebut mengakibatkan kematian, oleh karena itu, Cry dapat dimanfaatkan sebagai insektisida alami. Keuntungan dalam pemanfaatan kristal protein tersebut, bersifat toksik bagi larva nyamuk, namun tidak mencemari lingkungan dan aman terhadap organisme lain termasuk mammalia.

Penelitian terkait pemanfaatan B.thuringiensis telah banyak dilakukan diantaranya oleh Weyai (2004) yang menggunakan B.thuringiensis israelensis untuk melihat pengaruh mortalitasnya terhadap larva Ae. Aegypti melalui nilai LC $_{50}$ dalam 24 dan 48 jam. Widyastuti, dkk (1995) menguji kristal endotoksin B.thuringiensis $\mathrm{H}-14$ selama 24 jam untuk mengetahui nilai $\mathrm{LC}_{50} 90$ jam, yaitu sebesar 0,06 ppm. B. thuringiensis saat ini telah diformulasi dan dipasarkan, diantaranya formulasi Vectobac ${ }^{\circledR}$ dan VCRC B17®, yang biasa digunakan dengan dosis 1 sampai $25 \mathrm{mg} / \mathrm{L}$ di tempat-tempat penampungan air untuk mengendalikan populasi larva/jentik nyamuk dalam waktu 16 sampai 60 hari. Akan tetapi seringkali faktor penyimpanan mempengaruhi kualitas dari formulasi dan ditemukan formulasi yang sudah kadaluarsa. Formulasi yang sudah kadaluarsa mengakibatkan rendahnya efektifitas sehingga kematian larva rendah dan hal ini berpotensi memicu terjadinya resistensi larva nyamuk terhadap formulasi B. thuringiensis.

Melalui penelitian ini dilakukan uji efektifitas formulasi B. thuringiensis Vectobac ${ }^{\circledR}$ yang sudah kadaluarsa lebih dari 14 hari tanggal expired $(\mathrm{H}-14)$ dibandingkan dengan yang tidak kadaluarsa terhadap persentase mortalitas larva, yang dilihat dari nilai LC ${ }_{50}$ dan ${ }_{90} 48$ jam serta efak residunya. Hal ini untuk melihat sejauh mana penurunan toksisitas dari formulasi $B$. thuringiensis kadaluarsa dibandingkan yang tidak kadaluarsa.

\section{BAHAN DAN METODE}

Metode yang digunakan dalam penelitian adalah eksperimental dengan uji hayati (bioassay test), dengan 7 taraf dan 3 kali pengulangan yaitu : 0 ppm (Kontrol); 0,3 ppm; 0,1 ppm ; 0,07 ppm : 0,05 ppm, 0,03 ppm, 0,01 ppm (Weyai, 2004)

\subsection{Uji hayati mortalitas}

$100 \mathrm{~mL}$ suspensi formulasi $B$. thuringiensis VectoBac ${ }^{\circledR}$ (kadaluarsa H-14 dan tidak kadaluarsa) masing-masing diujikan terhadap terhadap 10 ekor larva pada 7 taraf konsentrasi. Parameter yang diamati adalah persentase kematian larva yang telah didedahkan selama 48 jam setelah perlakuan. Analisis data menggunakan analisis probit (Finney, 1971) untuk mendapat nilai $\mathrm{LC}_{50}$ pada 48 dan 90 jam.

\subsection{Uji hayati residu}

Suspensi formula $B$. thuringiensis yang menyebabkan $\mathrm{LC}_{90} 48$ jam ditambahkan $100 \mathrm{~mL}$ aquades diinfeksikan terhadap 10 ekor larva nyamuk, diamati tiap periode 48 jam untuk dicatat jumlah larva yang mati, dan pengamatan dihentikan bila telah tercapai $70 \%$ kematian larva.

\section{HASIL DAN PEMBAHASAN}

Pada penelitian ini formulasi B. thuringiensis yang diujikan terdiri dari 2 kategori yaitu Formulasi B. thuringiensis yang sesuai waktu penggunaan dan formulasi yang telah kadaluarsa (1 bulan dari expired date / batas tanggal kadaluarsa). Hasil uji mortalitas dari setiap konsentrasi $B$. thuringiensis tidak kadaluarsa dan kadaluarsa pada larva nyamuk $A e$. aegypti dapat dilihat pada Tabel 3.1

Dari Tabel 3.1 dapat dilihat bahwa mortalitas larva dalam waktu pengamatan 48 jam dengan konsentrasi tertinggi $0.3 \mathrm{ppm}$ mortalitas larva tidak mencapai $100 \%$. Mortalitas $50 \%$ terjadi pada larva yang diinfeksi formulasi $B$. thuringiensis kadaluarsa dengan konsentrasi $0.3 \mathrm{ppm}$ adapun pada formulasi yang tidak kadaluarsa mortalitas $50 \%$ larva terjadi pada konsentrasi yang jauh lebih rendah (0.05 ppm). Data ini menunjukkan bahwa dengan konsentrasi yang lebih kecil, formulasi $B$. thuringinensis yang tidak kadaluarsa sudah efektif membunuh larva nyamuk $50 \%$ dibandingkan dengan formulasi $B$. thuringiensis yang kadaluarsa.

Pada penelitian diketahui pula bahwa peningkatan konsentrasi formulasi $B$. thuringiensis yang kadaluarsa $(0,03 \mathrm{ppm}-0,1 \mathrm{ppm})$ tidak terlalu berpengaruh terhadap mortalitas larva ditunjukkan oleh niali mortalitas yang tetap sebesar $40 \%$, berbeda dengan formula yang tidak kadaluarsa semakin tinggi konsentrasi tingkat kematian pun semakin tinggi. Dengan demikian diketahui formulasi B.thuringiensis yang kadaluarsa telah mengalami penurunan efektifitas terhadap kematian larva Ae. Aegypti.

Larva Ae.aegypti pada Formulasi $B$. thuringiensis yang kadaluarsa dan tidak kadaluarsa Pada penelitian ini dilakukan penentuan konsentrasi yang tepat untuk menyebabkan $\mathrm{LC}_{50}$ dan $\mathrm{LC}_{90}$ dari $B$. thuringiensis yang kadaluarsa dan tidak kadaluarsa terhadap uji larva. Berikut ini nilai $\mathrm{LC}_{50}$ dan $\mathrm{LC}_{90}$ dari 
B. thuringiensis yang kadaluarsa dan tidak kadularsa terhadap larva pada waktu 48 jam yang disajikan pada
Tabel 3.2.

Tabel 3.1. Mortalitas Larva Ae. aegypti yang diinfeksi B. thuringiensis yang kadaluarsa dan yang tidak kadaluarsa

\begin{tabular}{cccc}
\hline Konsentrasi & $\begin{array}{c}\text { Jumlah Larva } \\
\text { Uji (ekor) }\end{array}$ & $\begin{array}{c}\text { Mortalitas Larva pada } \\
\text { Formulasi yang } \\
\text { Kadaluarsa (\%) }\end{array}$ & $\begin{array}{l}\text { Mortalitas Larva pa- } \\
\text { da Formu-lasi yg tdk } \\
\text { Kadaluar- } \\
\text { Sa (\%) }\end{array}$ \\
\hline Kontrol & 30 & 0 & 0 \\
$0,3 \mathrm{ppm}$ & 30 & 50 & 63,3 \\
$0,1 \mathrm{ppm}$ & 30 & 40 & 56,6 \\
$0,07 \mathrm{ppm}$ & 30 & 40 & 56,6 \\
$0,05 \mathrm{ppm}$ & 30 & 40 & 53,3 \\
$0,03 \mathrm{ppm}$ & 30 & 40 & 46,6 \\
$0,01 \mathrm{ppm}$ & 30 & 36.6 & 43,3 \\
\hline
\end{tabular}

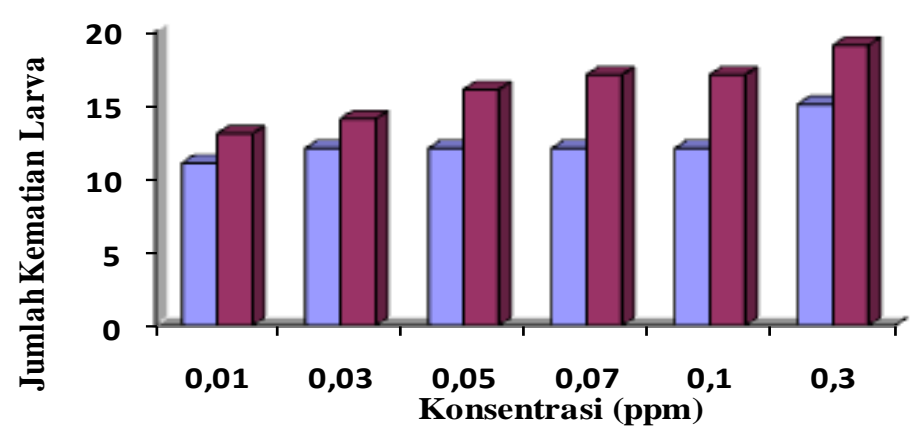

Gambar. 3.1 : Grafik Perbandingan Jumlah Kematian

Tabel 3.2. Nilai LC50 dan LC 9048 Jam dari formulasi B. thuringiensis yang kadaluarsa dan yang tidak kadaluarsa

\begin{tabular}{lcc}
\hline \multicolumn{1}{c}{ Jenis Formulasi } & $\begin{array}{c}\mathbf{L C}_{\mathbf{5 0}} \\
(\mathbf{p p m})\end{array}$ & $\begin{array}{c}\mathbf{L C}_{\mathbf{9 0}} \\
(\mathbf{p p m})\end{array}$ \\
\hline $\begin{array}{l}\text { B. thuringiensis yang } \\
\text { kadaluarsa }\end{array}$ & 0,305 & 1,513 \\
$\begin{array}{l}\text { B. thuringiensis yang } \\
\text { tidak kadularsa }\end{array}$ & 0,036 & 0,897 \\
\hline
\end{tabular}

Formulasi B.thuringiensis yang tidak kadularsa dengan konsentrasi yang lebih rendah telah memiliki efek toksisitas terhadap larva Ae.aegypti, dibandingkan formulasi $B$. thuringiensis yang kadaluarsa. Dari Nilai $\mathrm{LC}_{50} \& \mathrm{LC}_{90} 48$ jam formulasi tidak kadularsa lebih toksik dibandingkan dengan $B$. thuringiensis yang kadaluarsa. Hal ini diduga terjadi karena kualitas dan kuantitas toksin dari formulasi B. thuringiensis yang kadaluarsa mengalami penurunan karena sudah melewati masa simpan. Kedua formulasi $B$. thuringiensis tersebut memiliki cara kerja yang sama dalam menyerang larva $A e$. aegypti, akan tetapi konsentrasi yang menyebabkan kematian $50 \%$ dan $90 \%$ berbeda. Konsentrasi formulasi $B$. thuringiensis dilihat dari nilai $\mathrm{LC}_{50} 48$ jam. Toksisitas Formulasi $B$. thuringiensis yang kadaluarsa berkurang 5 kali lipat dibandingkan dengan formulasi $B$. thuringiensis yang belum kadaluarsa.

\section{Uji Residu B. thuringiensis terhadap larva Aedes aegypti}

Penelitian ini dimaksudkan untuk mengetahui waktu kematian yang diperlukan residu $B$. thuringiensis yang dapat mematikan larva sampai $70 \%$ dari jumlah awal larva. Pengamatan dilakukan tiap 48 jam. Konsentrasi B. thuringiensis yang digunakan adalah $\mathrm{LC}_{90} \quad 48$ Jam yang diperoleh dari uji hayati. Kematian larva hingga hari ke-2 (48 jam pertama) sebesar $100 \%$ terus menurun sampai dengan $70 \%$ di hari ke-14 (Gambar.3.2) untuk formulasi tidak kadaluarsa adapun untuk formulasi yang kadaluarsa 
formulasi $B$. thuringiensis efektif mengakibatkan kematian larva hingga $70 \%$ hanya sampai hari ke-12 dan tidak terjadi kematian $100 \%$ di 48 jam pertama pengujian (Gambar 3.3) . Hal ini menunjukkan bahwa

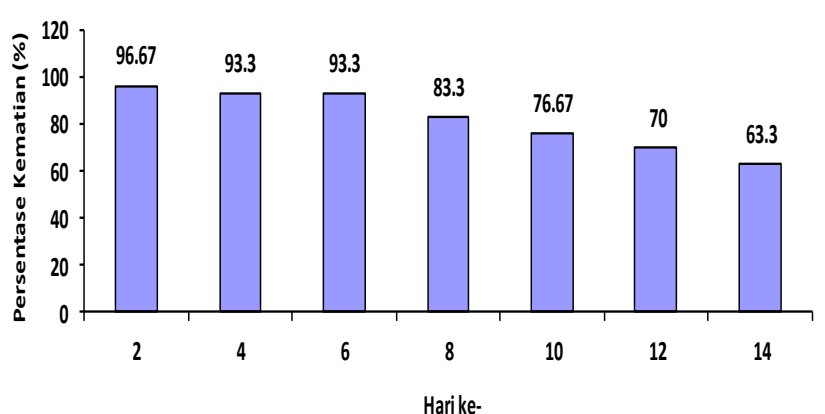

Gambar.3.2 : Grafik Persentase Kematian Larva Ae.aegypti Pada Uji Residu Formulasi $B$. thuringiensis yang Tidak Kadaluarsa

Larvasida $B$. thuringiensis di dalam suspensi dapat menurun toksisitasnya diantaranya disebabkan oleh perubahan dan $\mathrm{pH}$. Protein endotoksin yang terdapat di $B$. thuringiensis sangat sensitif terhadap paparan sinar ultraviolet (Mulla, 1985). Ada beberapa faktor yang turut serta mempengaruhi kemampuan formulasi Bacillus thuringiensis dalam membunuh larva. Adapun faktor-faktor tersebut adalah:

Faktor Pertama disebabkan kebiasan makan dari larva Aedes aegypti, larva Ae.aegypti ini mempunyai kebiasaan mengambil makanan di dasar dan dinding tempat penampungan air (bottom feeders). Hal ini dapat mempengaruhi daya bunuh spora $B$. thuringiensis dimana kebiasaan makan larva tersebut dengan keberadaan endapan dari spora B.thuringiensis.

Faktor Kedua disebabkan tersedianya toksin di daerah makan larva (larval feeding zone). Keberadaan toksin dari B.thuringiensis pada daerah makan larva tersebut sangat mempengaruhi daya bunuhnya. Larva yang mengambil makan pada dasar penampungan akan lebih cepat mati dibandingkan yang makan di daerah permukaan saja. Dilaporkan bahwa jumlah spora bakteri B.thuringiensis adalah sama banyak dipermukaan dan dasar air pada hari ke 3 dan ke 7 sesudah aplikasi (Blondine, 2004).

Faktor Ketiga disebabkan oleh tingkat kerentanan larva terhadap toksin yang dihasilkan Masing-masing larva memiliki kerentanan yang berbeda-beda terhadap konsentrasi toksin dari B.thuringiensis. Tingkat instar larva dari I, II, III dan IV memiliki daya tahan terhadap toksin juga berbeda. Hal ini juga menyebabkan perbedaan konsentrasi toksin yang harus diberikan terhadap larva tersebut. Dilaporkan bahwa besar kecilnya konsentrasi B.thuringiensis dalam mematikan larva, tergantung pula pada tingkat toksin B. thuringiensis yang tidak kadaluarsa lebih bertahan disuspensi dibandingkan Formulasi $B$. thuringiensis yang sudah kadaluarsa.

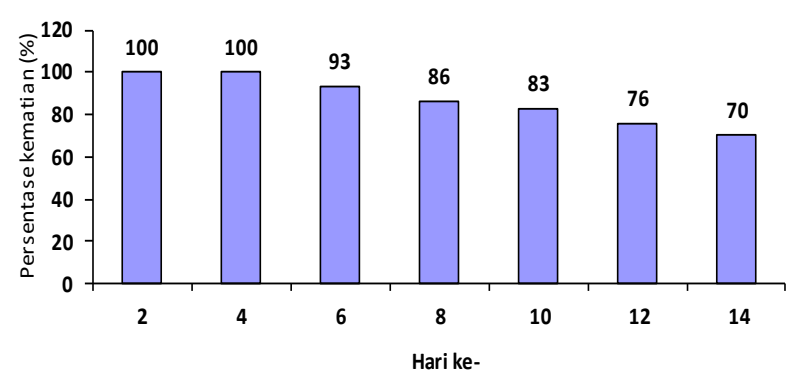

Gambar.3.3 : Grafik Persentase Kematian Larva Ae.aegypti Pada Uji Residu Formulasi $B$. thuringiensis yang Kadaluarsa

kerentanan larva sasaran terhadap toksin yang dihasilkan (Knowles, 1993).

Toksin B. thuringiensis sangat spesifik terhadap serangga inang, tergantung pada struktur toksin dan kehadiran reseptor toksin dalam midgut serangga. Toksin tersebut berikatan dengan reseptor khusus yaitu kaderin dan aminopeptidase yang terdapat pada membran sel epitel usus tengah. Ikatan reseptor fragmen beracun tersebut membentuk poripori dan menyebabkan kebocoran pada epitelium usus tengah sehingga permeabilitas dan fungsi sel terganggu dan menggangu transfer ion $\mathrm{Na}^{+}$dan $\mathrm{K}^{+}$. Peran reseptor toksin dalam membentuk formasi pori pada tingkat molekuler masih belum dipahami dengan baik (Knowles and Dow, 1993). Epitelium usus tengah yang mengalami kebocoran akan mempermudah masuknya spora B.thuringiensis dan bakteri lain yang ada di saluran pencernaan ke dalam rongga tubuh serangga. Bakteri tersebut akan menggunakan hemolimf serangga sebagai media pertumbuhan. Setelah 2-3 hari, septisemia yang disebabkan oleh B.thuringiensis akan menyebabkan kematian serangga (Weinzierl, et al., 1997; Khetan, 2001).

Pembentukan pori yang terjadi akan menyebabkan sel-sel membengkak dan akhirnya lisis. Model yang dibuat oleh Knowles dan Dow (1993) menekankan pada penghentian pompa $\mathrm{K}^{+}$yang mengarah ke pembengkakan sel kolumnar dan lisis osmotik. Gangguan integritas usus inilah yang akhirnya menyebabkan kematian.

Pada penelitian ini juga dilakukan pengamatan pada larva yang mati terinfeksi $B$. thuringiensis (Gambar 3.4) menunjukkan bahwa larva Ae.aegypti yang terinfeksi oleh B.thuringiensis membuat sel membengkak dan akhirnya lisis atau pecahnya isi sel ke bagian lumen. 
(A)

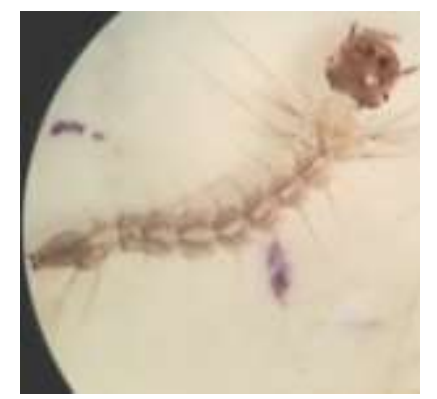

(B)

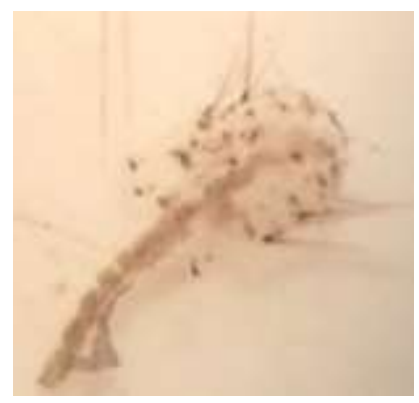

(C)

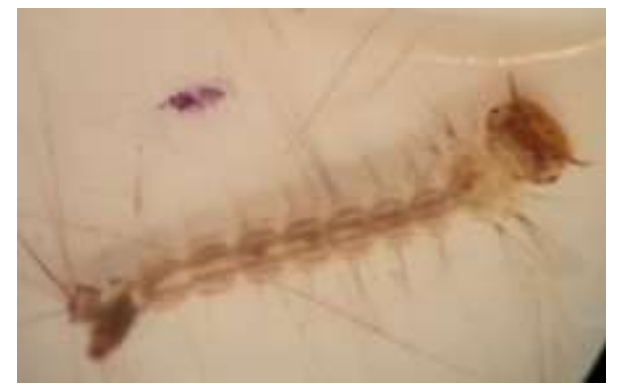

Gambar 3.4. (A) Larva Ae.aegypti yang telah terinfeksi toksin B. thuringiensis yang telah didedahkan selama 48 jam dengan ditandai dengan membengkaknya sel dengan lekukan yang lebih tajam dan kosongnya ruangan pada tiap segmen; (B) terjadinya lisis atau pecahnya isi sel ke bagaian lumen ; (C) Larva Ae.aegypti yang tidak diberi perlakuan $($ Kontrol) $($ perbesaran $=100 \times)($ Sumber $:$ Data Primer).

\section{KESIMPULAN}

Efektifitas formulasi $B$. thuringiensis yang kadaluarsa (H-14) telah jauh menurun (5 kali lipat) dibandingkan formulasi $B$. thuringiensis yang tidak kadaluarsa, hal ini terbukti dari nilai $\mathrm{LC}_{50}$ dan $\mathrm{LC}_{90}$ formulasi $B$. thuringiensis yang kadaluarsa $(\mathrm{H}-14)$ $0,305 \mathrm{ppm}$ dan $1,513 \mathrm{ppm}$ jauh lebih tinggi dari nilai $\mathrm{LC}_{50}$ dan $\mathrm{LC}_{90}$ formulasi yang tidak kadaluarsa yaitu 0,036 ppm dan 0,897 ppm. Toksisitas formulasi $B$. thuringiensis kadaluarsa (H-14) yang telah menurun terlihat pula dari efek residu $B$. thuringiensi kadaluarsa terhadap larva Ae. Aegypti efektif hanya hingga hari ke-12, adapun $B$. thuringiensis yang tidak kadaluarsa efektif hingga hari ke-14.

\section{UCAPAN TERIMA KASIH}

Penelitian ini terselenggara melalui bantuan dana riset Hibah Kompetensi Nasional tahun 2015, untuk itu ucapan terimakasih kami berikan kepada DPMPI Unpad dan Dirjen Ristekdikti.

\section{DAFTAR PUSTAKA}

Sutrisno, S. 1991. Current fruit fly problem in Indonesia. K. Kawasaki, O. Iwashashi, and K.Y. Kaneshiko (Eds.).Proceeding of the International Symposium on the Biology and Control of Fruit Files.Okinawa Prefecture. p. $72-78$

Blondine Ch.P. 2004. Efektivitas Vectobac 12 AS (Bt $\mathrm{H}-14)$ dan Bacillus thuringiensis $\mathrm{H}-14$ terhadap vektor malaria Anopheles maculatus di kobakan desa Hargotirto, kecamatan Kokap, kabupaten Kulon Progo. Buletin Penelitian Kesehatan. 32(1): 17-28

Boesri, H. \& D.T. Boewono. 2008. Perbandingan kematian nyamuk Aedes aegypti pada penyemprotan aerosystem menggunakan bifenthrine dengan system thermal fogging menggunakan malathion. Jurnal kedokteran Yarsi. 16(2): 130-14.

Depkes RI, 2007. Pemberantasan Serangan Nyamuk Demam Berdarah Dengue (PSN DBD). Edisi : ke tiga. Depkes Dirjen PP dan PL. Jakarta

Fathi, S, Keman, \& Wahyuni, C.U. 2005. Peran Faktor Lingkungan dan Perilaku Terhadap Penularan Demam Berdarah Dengue di Kota Mataram. Jurnal Kesehatan Lingkungan 2(1): $1-10$

Finney, D.J. 1971. Probit Analysis. Cambridge University Press. London, 125 pp.

Khetan, S.K. (2001). Microbial Pest Control. Marcel Dekker, Inc. USA. $141 \mathrm{pp}$.

Knowles, B.H. \& J.A.T. Dow. 1993. The crystal delta-endotoxins of Bacillus thuringiensis: models for their mechanism of action on the insect gut. Bioassays, 15, p. 469-476

Mulla, M.S. 1986. Role of Bti and Bacillus sphaericus in mosquito control programs, in fundamental and applied aspects of invertebrate pathology, Foundation of the 4th Int'l Colloq. of Invertebrae. Pathol. p. 494-496

Weinzier, R., T. Henn \& P.G. Koehler. 1997. Microbial Insecticides. University Of Florida publication ENY. 275 pp.

Weyai, M.N. 2004. Efikasi Bacillus thuringiensis H14 (Vectobac WDG) terhadap larva nyamuk Aedes aegypti di Laboratorium.Laporan Skripsi. Universitas Diponegoro Semarang

Widyastuti, U., Widiarti \& Blondine Ch. 1995. Uji Coba Bacillus thuringiensis H-14 Terhadap Larva Nyamuk Anophles Barbirostris di Laboratorium dan Lapangan. Buletin Penelitian Kesehatan Vol 23.

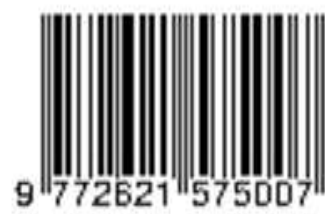

